\title{
ALVES, Maria Theresa Abelha. O real transfigurado: literatura e cinema. Belo Horizonte: Veredas \& Cenários, 2012.376 p.
}

Lélia Parreira Duarte Universidade Federal de Minas Gerais

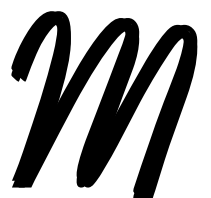

aria Theresa Abelha Alves é uma estudiosa atenta, uma pesquisadora nata (e certamente uma extraordinária professora). Basta lembrar algumas de suas memoráveis publicações: A dialectica da camuflagem nas Obras do Diabinho da mão furada, sua tese de doutorado, publicada pela Imprensa Nacional - Casa da Moeda, em1983; seus dois livros sobre Gil Vicente (1995 e 2002), suas numerosas reflexões sobre o Barroco e o Padre António Vieira, seus ensaios sobre a literatura portuguesa de várias épocas e, especialmente, seus notáveis estudos da obra dos contemporâneos Agustina Bessa-Luís, Mário Cláudio e Manoel de Oliveira.

Por isso mesmo, O real transfigurado: literatura e cinema apresenta-se como indispensável a quem se debruça sobre a obra do que ela chama "uma família lítero-cinematográfica", reunida pelo olhar fascinado e atento - na "Tetralogia dos amores funestos" - pelo cineasta Manoel de Oliveira, numa arte que se faz de "desleituras", fingimentos e citações, com a consciência pós-moderna de que "a arte discute suas formas e materiais, discursa sobre si, declara os princípios estéticos que a conformam" (p.346), transfigurando o real para que leitores e espectadores possam imaginar melhor a vida. 
Theresa começa pelos olhares cruzados dos três artistas contemporâneos - Agustina Bessa-Luís, Mário Cláudio e Manoel de Oliveira - que focalizam como "ilhas de significância" a vida e a obra passionais de Camilo Castelo Branco, acompanhando esses autores na síntese semiótica com que ilustram a identidade do norte de Portugal. Para isso detém-se, pertinentemente, em obras dos autores privilegiados no trabalho: Agustina BessaLuís, com seu Vale Abraão (baseado em Madame Bovary, de Flaubert) e Fanny Owen (inspirado em textos de Camilo Castelo Branco, e nos diários de Francisca Owen e de José Augusto Pinto de Magalhães), transformados em filmes por Manoel de Oliveira; e Camilo Broca, de Mário Cláudio, em que o fecundo escritor portuense recria a figura de Camilo, através de três narradores, Camilo, sua irmã e um outro que muitas vezes se confunde com Camilo, ao acompanhar várias gerações dessa família marcada pela paixão e pela tragicidade.

Analisa depois, minuciosa e pertinentemente, as "traduções" baseadas em traições - dessemelhanças criativas - feitas por Manoel de Oliveira das obras de Camilo que inspiraram Agustina e Mário Cláudio e artisticamente elaboradas pelo cineasta que fala da cidade amada, em "Porto da minha infância". Mostra para isso uma série de artifícios utilizados pelo cineasta na composição dos filmes: o descompasso entre som e imagem, o constante uso do simulacro e de artifícios de outras artes, como a pintura, a multiplicação de pontos de vista, a propriedade no uso da trilha sonora e do figurino que indica situações e confrontos entre classes sociais, a sugestão de falar do desejo de desejar e da "relação que a linguagem mantem com a morte: dizer o indizível, mistério em que se nega e se cria"(p.136), pois o "que se quer dizer é inacessível à linguagem" (p. 141).

Theresa fala ainda do confronto entre cinema e teatro nessas e em outras obras do cineasta, que usa muitas vezes o 
artifício de manter a câmara parada para ilustrar as fantasmáticas e obsessivas presenças que não lhe saem da memória.

Mas para elaborar essas análises, entretecidas com resumos analíticos e interpretações argutas do simbolismo de textos e imagens, e que dirigem com segurança o leitor pelas vias da literatura e do cinema, Theresa não o dispensa de procurar ler os romances ou assistir aos filmes; pelo contrário, instiga o seu interesse e curiosidade, pois acentua sempre a ambiguidade e o caráter de representação das obras, sublinhando o seu olhar de leitora ou espectadora e o caráter dessa arte que fala do real e sabe que não pode reproduzi-lo, repetindo assim Fernando Pessoa: aquela outra coisa é que é linda...

Theresa muitas vezes esclarece suas referências (são inúmeros os textos teóricos e literários - que vão dos mais tradicionais aos mais recentes - usados em suas reflexões), mas conta também com o entendimento do leitor, o que aumenta a sedução de seu instigante texto e exemplifica a sua perspectiva de que sem interação entre o espectador e a obra (e também, certamente, entre o crítico e o leitor) o milagre da arte (ou a sua fruição) não acontece (p. 265).

Demonstrando que a memória de Camilo, Agustina, Mário Cláudio e Manoel de Oliveira são fundamentais para a obra desses artistas que sabem, como Proust, que redescobrir o tempo é regressar aos paraísos perdidos que estão sempre no passado, Theresa discretamente exibe a sua erudição e a importância das obras analisadas, fundamentais para uma revisão histórica, ética, política e artística do Portugal de várias épocas. 